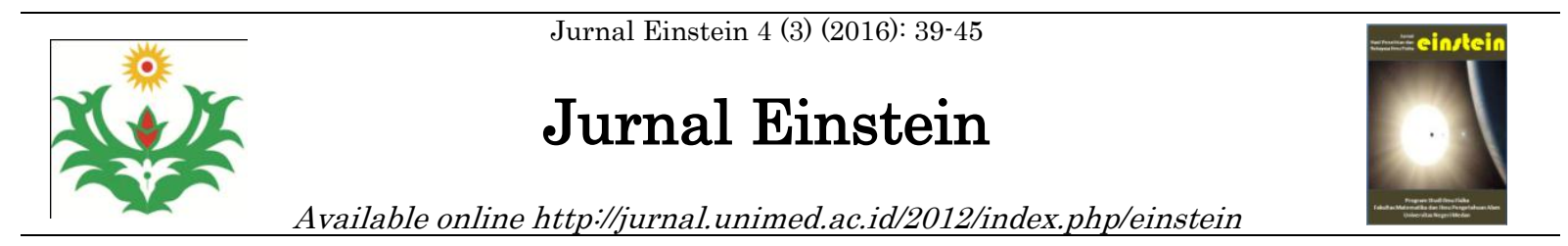

\title{
Preliminary Study on Small Long-Life PWR Reactor Design Fueled Thorium with Protactinium as Burnable Poison
}

\author{
Jubaidah* \\ Jurusan Fisika, Fakultas Matematika dan Ilmu Pengetahuan Alam, Universitas \\ Negeri Medan, Indonesia
}

Diterima Agsutus 2016; Disetujui September 2016; Dipublikasikan Nopember 2016

\begin{abstract}
Abstrak
Thorium as fissile material has overweigh advantages compared to Uranium in order to have a long-life PWR reactor without replacement fuel. Additional of Protactinium as a burnable poison is effective to reduce excess reactivity in the beginning of the reactor operation. This study aims to analyze the neutronic, burnup fuel, thermalhydraulic and kinetic calculations in regard to reactor safety. The calculation is performed with SRAC program using JENDL-32 as data library. The results show that the value of $\mathrm{k}_{\text {eff }}$ for 33 years are still in the range $1.0154<\mathrm{k}_{\text {eff }}<1.0171$ and the burn-up level has increased, due to the additional fissile material as conversion results of Th232 and Pa231. Axial linear power distribution indicates normal distribution pattern. The coolant temperature distribution in the axial direction is quite flat.
\end{abstract}

Key words: PWR, Th-232, U-233, Pa-231, neutronic, thermal-hydraulic, burn-up level, reactor kinetics

How to Cite: Jubaidah, (2016), Preliminary Study on Small Long-Life PWR Reactor Design Fueled Thorium with Protactinium as Burnable Poison, Jurnal Einsten Prodi Fisika FMIPA Unimed, 4 (3) : 39-45.

E-mail:jubaidah@unimed.ac.id p-ISSN : $2338-1981$ e-ISSN : $2407-747 \mathrm{x}$ 


\section{INTRODUCTION}

Thorium (Th-232) is fertile element for thermal nuclear reactors that has many advantages compared to Uranium (U-238). Natural Thorium is three times more abundant than natural Uranium. Absorption cross-section of Th$232(7,6 \mathrm{~b})$ is three times higher than U238 (2,7b). The amount of neutron absorption ability of the fertile element will affect the overall conversion rate, and also will reduce the capture of neutrons in the moderator and structure. These unique characteristics can be employed in Pressurized Water Reactor (PWR) design without the need for replacement fuel in a considerable period of time. In addition, $\mathrm{ThO}_{2}$ has high boiling point $(4,670 \mathrm{~K})$ and thermal conductivity, so it can increase reactor safety limits. ${ }^{[1]}$ The thorium reactors are also highly resistant to material income-arms (weaponsproliferation material). Furthermore, Th232 produces less minor actinides than U238. The results of the low radioactivity in thorium will provide benefits in the management of nuclear waste. In addition, the melting point of $\mathrm{ThO}_{2}$ around $500{ }^{\circ} \mathrm{C}$ higher than with $\mathrm{UO}_{2}\left(3300{ }^{\circ} \mathrm{C}: 2800{ }^{\circ} \mathrm{C}\right)$.

$\mathrm{Pa}-231$ is a burnable poison that is effective to reduce excess reactivity in the beginning of the operation of the reactor. $\mathrm{Pa}-231$ has a neutron capture cross section of 200b. Pa-231 is also fertile element that can mutate into fissile nuclide U-232 which then becomes $\mathrm{U}-233$. Fissile elements produced by $\mathrm{Pa}^{-}$ 231 can compensate the reactivity reduction during operation. This characteristic is used to get the long life of the reactor. ${ }^{[2][3]}$

Regarding reactor safety during the operation, there are four main things that need to be considered, namely; neutronic analysis, analysis of fuel burnup, thermal-hydraulic analysis and kinetic analysis for reactor safety. This research aims to analyze neutronic, fuel cells, thermal-hydraulic, and kinetic calculation of the PWR type reactor fueled Th-Pa-U oxide. Calculation is performed with SRAC program using JENDL-32 as data library and Prenpacv1.0. ${ }^{[4]}$

\section{METHODS AND MATERIALS}

The methodology in this research consists of neutronic, fuel burn-up, thermal-hydraulic calculation as well as kinetic analysis. Neutronic calculation is a very important aspect in nuclear reactor to analyze the neutron distribution within the reactor core to yield the required power generation. ${ }^{[5]}$ SRAC program ${ }^{[6]}$, a comprehenship neutronics calculation code system for various types of thermal reactors, is employed to analyze the reactor systems based on existing data library developed by JAERI Japan. In this project, JENDL32 is used as data library.

The expression of neutron behavior in a steady state satisfies the integral form of Boltzman transport equation, known as Neutron transport equation ${ }^{[5]}$ that

$\frac{1}{v} \frac{\partial \varphi}{\partial}+\vec{\Omega} \cdot \vec{\nabla} \varphi+\Sigma_{t} \varphi=\int_{4 \pi} d \hat{\Omega}^{\prime} \int_{0}^{\infty} d E^{\prime} \Sigma_{s}\left(E^{\prime} \rightarrow E, \hat{\Omega}^{\prime} \rightarrow \Omega\right) \varphi+S(\vec{r}, E, \hat{\Omega}, t)$

where

$S$ = neutron source rate

$\vec{r}=$ neutron position

$\hat{\Omega}=$ angular volume element

$\mathrm{E}=$ energy

$\mathrm{v}=$ neutron velocity

$\varphi=$ neutron flux

$\Sigma_{s}=$ macroscopic scattering cross- $^{-}$ section

$\Sigma_{t}=$ total of macroscopic cross-section

Suppose that two successive fission neutron generations could somehow be measured. The Ratio of a number of neutrons in one generation compare to the previous generation is defined as multiplication factor (K) that can show characteristic of the chain reaction. Effective multiplication factor $\left(\mathrm{K}_{\text {eff }}\right)$ is obtained by taking into account the geometry (size terrace) in detail. [4] The condition of the reactor criticality is determined by the multiplication factor. If $\mathrm{K}_{\text {eff }}<1$ it 
means that the reactor is in subcritical condition, when $\mathrm{K}_{\text {eff }}=1$ then the reactor is in critical condition. Meanwhile, if $\mathrm{K}_{\text {eff }}>1$, reactor is under supercritical conditions. Modification in core design and composition of fuel can affect the value of $K_{\text {eff. }}$

The economics of nuclear power is strongly affected by changes in the composition of nuclear reactor due to fuel burnup over its lifetime. As nuclear reactor engineers, one must consider the consumption rate of fissile material, the conversion of fertile material into fissile material, the concentration of burnable poison and thousands of fission products produced within the core. Even for small changes have important role to control the reactor stability. Calculation in regard these features is called fuel-burnup analysis.

The general procedure in the calculation of burnup analysis defined in equation 2.3. If $N_{A}(r, t)$ is a number of nuclide density type $A$, so the reaction rate is

$$
\begin{aligned}
& \frac{d N_{A}}{d t}=-\lambda_{A} N_{A}-\left[\sum_{g} \sigma_{g}^{A} \phi_{g}\right] N_{A}+= \\
& \lambda_{B} N_{B}+\left[\sum_{g} \sigma_{g}^{C} \phi_{g}\right] N_{C} \\
& \text { where: } \\
& \lambda_{A} N_{A}=\text { Dismissed nuclide due to } \\
& \text { decay } \\
& \lambda_{B} N_{B}=\text { Nuclide } \mathrm{A} \text { is formed due to } \\
& \begin{array}{l}
{\left[\sum_{g} \sigma_{g}^{A} \phi_{g}\right] \begin{array}{l}
\text { Nuclide } \mathrm{A} \text { is miss due to } \\
\text { neutron absorption }
\end{array}} \\
{\left[\sum_{g} \sigma_{g}^{C} \phi_{g}\right] \begin{array}{l}
\text { Nuclide } \mathrm{A} \text { is formed due to } \\
\text { transmutation from nuclides } \\
\mathrm{C} \text { to } \mathrm{A} .
\end{array}}
\end{array}
\end{aligned}
$$

Thermal-hydraulic analysis aims to determine the cycle of power on the terrace and the coolant temperature distribution as the heat transfer. It is very important to determine standardization of reactor safety and become a major parameter in determining the coolant temperature distribution. ${ }^{[3]}$
The power density per unit cc stating the amount of power generated per unit volume in a single mesh. Calculation of power density in the reactor core can be calculated using the following equation

$q^{\prime \prime \prime}(r)=E_{f} \Sigma_{f} \phi(r)$

with

$q^{\prime \prime \prime}(r)=$ volumetric power density $\left(\mathrm{Watt} / \mathrm{cm}^{3}\right)$

$E_{f}=$ released energy at fission reaction (Joule)

$\Sigma_{f}=$ fission macroscopic cross section $\left(\mathrm{cm}^{-1}\right)$

As for the linear power density in the fuel rods can be formulated as follows:

$$
q^{\prime}=q^{\prime \prime \prime}\left[\frac{\pi r_{\text {rod }}^{2}}{F_{\text {fuel }}+F_{\text {clad }}}\right]
$$

where,

$q^{\prime}=$ linear power density $(\mathrm{W} / \mathrm{cm})$

$r_{\text {rod }}=$ radius of fuel $\operatorname{rod}(\mathrm{cm})$

$F_{\text {fuel }}=$ fuel fraction

$F_{\text {clad }}=$ cladding fraction

At the time of the coolant flowing through the fuel rods through the coolant channel, will occur convection heat transfer from the surface of the fuel rod to the coolant flow. The increase in coolant temperature is calculated using energy equivalence. The produced energy by the fuel along $\mathrm{dz}$ must be equal to the absorbed energy when the coolant flows through $\mathrm{dz}$.

$\dot{m} c_{p} d T=q^{\prime}(z) d z$

Where the linear power density $q^{\prime}(z)$ defined as follows

$q^{\prime}(z)=q^{\prime}{ }_{0} \cos \left(\frac{\pi z}{H}\right)$

Reactor kinetics is the study of neutron power changes with time. Reactor kinetics analysis is a crucial aspects to keep the reactor operate safely when it is started, during the operation and shut downed. ${ }^{[3]}$ The main parameter in reactor kinetic analysis is reactivity $(\rho)$.

$$
\rho=\frac{k_{e f f}-1}{k_{e f f}}
$$


$\rho=0 \rightarrow$ critical condition, fission reaction is constant

$\rho>0 \rightarrow$ supercritical condition, fission reaction increase,

$\rho<0 \rightarrow$ subcritical condition, fission reaction decrease

PWR reactor design specifications used in this research are as follows.

Table 1. Specifications of neutronic calculations

\begin{tabular}{cc}
\hline Parameter & Specifications \\
\hline $\begin{array}{c}\text { Core thermal } \\
\text { power }\end{array}$ & $23 \mathrm{MWt}$ \\
Refueling Period & 35 tahun \\
Geometry Terrace & $\begin{array}{c}\text { Cylinder Tall 2-D } \\
\text { (R-Z) }\end{array}$ \\
Terrace & $\begin{array}{c}\text { Small-long life core } \\
480 \mathrm{~cm} \mathrm{x} 600 \mathrm{~cm}\end{array}$ \\
Characteristics & $40 \mathrm{~cm} \mathrm{x} \mathrm{50} \mathrm{cm}$ \\
- Active size (DxZ) & \\
- Reflector (LxT) & Th-Pa-U oxide \\
Fuel & $8 \%$ \\
-Enrichment U-233 & $7,8 \%$ \\
-Percentage Pa-231 & $60 \%: 10 \%: 30 \%$ \\
Volume fraction & \\
(F:C:M) & Zircalloy $(\mathrm{Zr})$ \\
Cladding & Light water $\left(\mathrm{H}_{2} \mathrm{O}\right)$ \\
Coolant & $10.0 \mathrm{~g} / \mathrm{cm}^{3}$ \\
Fuel density & $1.0 \mathrm{~g} / \mathrm{cm}^{3}$ \\
H ${ }_{2} \mathrm{O}$ density & Square cell \\
Pin cell type & $1,4 \mathrm{~cm}^{2}$ \\
Pin pitch & $1,224 \mathrm{~cm}^{2}$ \\
\hline Pin Diameter &
\end{tabular}

Table 2. Specifications of thermalhydraulics calculation

\begin{tabular}{cc}
\hline Parameter & Specifications \\
\hline $\begin{array}{c}\text { Energy per fission } \\
(\mathrm{MeV})\end{array}$ & 192.2 \\
T-inlet of Coolant & $300{ }^{\circ} \mathrm{C}$ \\
Pressure System & $155 \mathrm{bar}$ \\
Density of coolant inlet & $0.72 \mathrm{~g} / \mathrm{cm}^{3}$ \\
Thermal expansion & $1.50485 \mathrm{E}-3$ \\
coefficient & \\
Heat capacity & $4.2 \mathrm{~J} / \mathrm{g} .{ }^{\circ} \mathrm{C}$ \\
Water coolant flow rate & $50 \mathrm{~g} / \mathrm{s}$ \\
Fanning constants & $1.50 \mathrm{E}-1$ \\
Fluid viscosity & $1.0 \mathrm{E}-3$ \\
\hline
\end{tabular}

\section{RESULT AND DISCUSSION}

The result of nutronic calculation for 35-year reactor operation using SRAC is shown in figure 1 . The $\mathrm{k}_{\text {eff }}$ is decline sharply at the beginning of the operation due to the effect of the addition of $\mathrm{Pa}-231$ as a burnable poison which managed to suppress the excess reactivity.

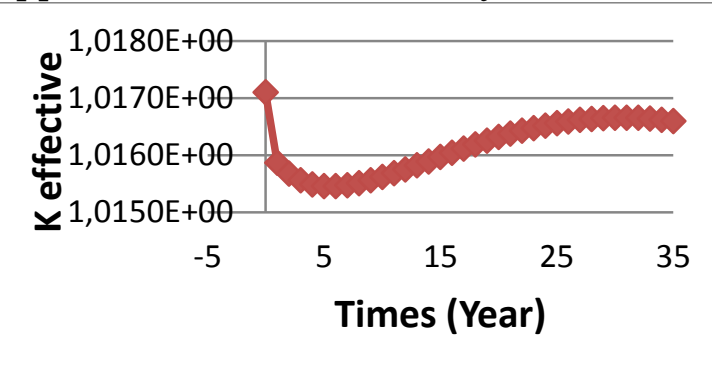

Figure 1. keff profile

Burnup level rises linearly from beginning to end of burnup process (Figure 2) due to the fuel undergo fission. The more fission products formed the greater the power generated.

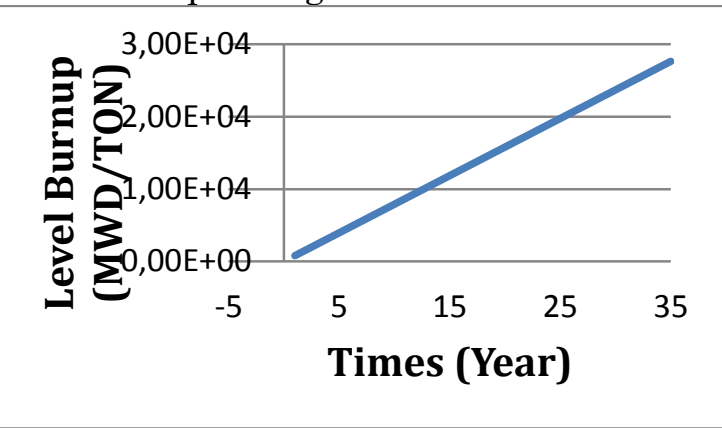

\section{Figure 2. Burnup Level}

Burnup process changes the atomic density. Density of Th-232 continued to decline (Figure 3) due to neutron-induced and converted into Th231 which then becomes $\mathrm{Pa}-231$ after $\beta^{-}$ decay.

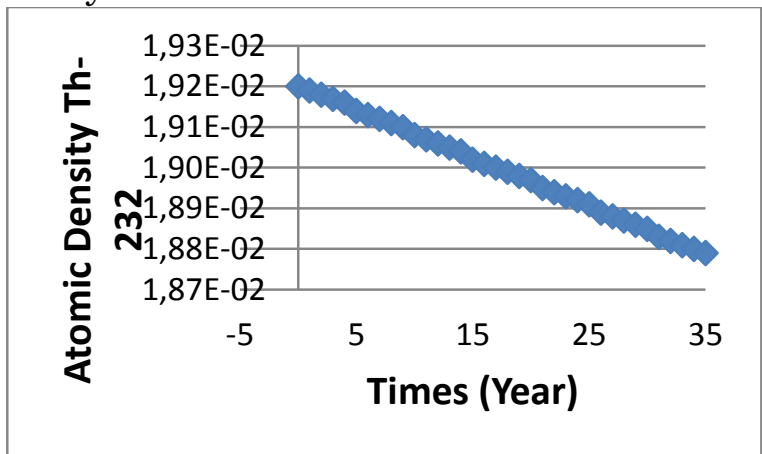

Figure 3. Density changes of Th-232 
Figure 4 shows the amount of $\mathrm{Pa}^{-}$ 231 decreased significantly. Meanwhile density of U-233 decreased slightly due to additional U-233 obtained from $\mathrm{Pa}-232$ and U-232 neutron induced or $\mathrm{Pa}-233$ by $\beta^{-}$decay. In the other hand, U-232 appear and then increase considerably as new fissile materials as conversion of $\mathrm{Pa}-232$.

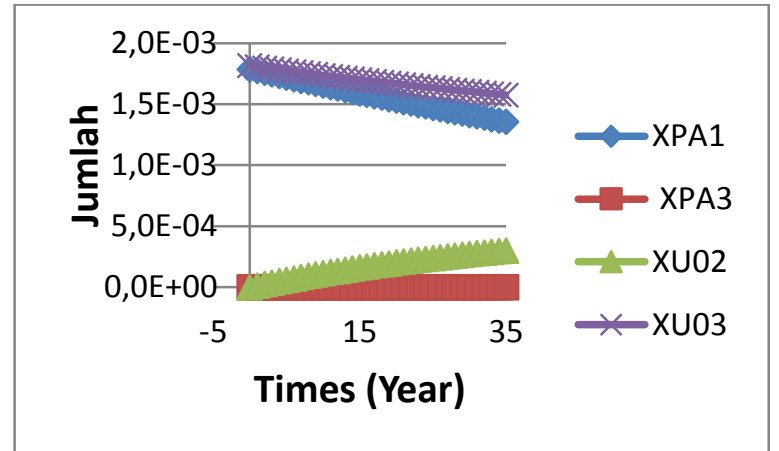

Figure 4. Comparison of fuel change

Base on the result of thermalhydraulic calculation, linear power density in the axial direction (figure 5) shows the maximum point is located in the center of the reactor. Meanwhile, the minimum power is located at under and above the reactor core directly adjacent to the reflector. The highest probability of neutron leakage is in the section near the reflector. This is happened due to the homogeneous fuel arrangement.

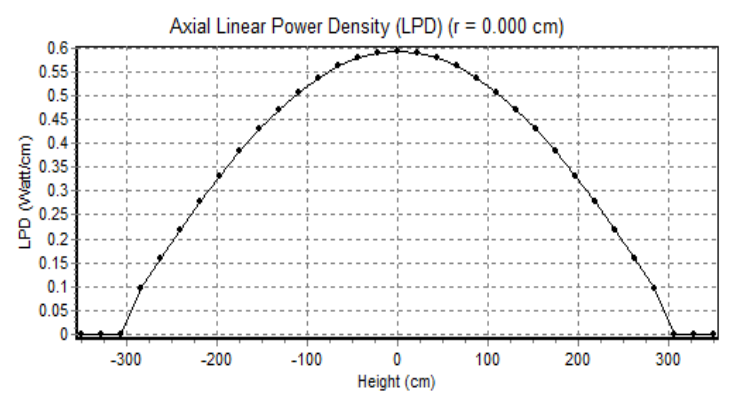

Figure 5. Linear power density in axial

Linear power distribution in the radial direction (figure 6) is not uniform. At the reactor base, $0-75 \mathrm{~cm}$ from the bottom, power density is at the level of 0.6 watt $/ \mathrm{cm}$. Then, from $80-100 \mathrm{~cm}$, the power density soar at $0.8 \mathrm{watt} / \mathrm{cm}$ before falling down sharply to zero point.

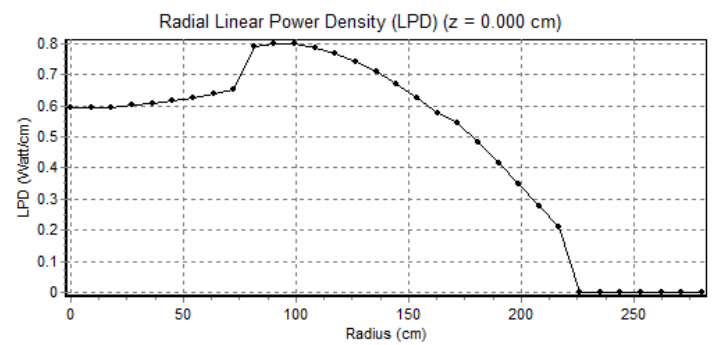

Figure 6. Linear power density in radial

The coolant temperature distribution in the axial direction was calculated using Prenpac v1.0 code (figure 7 and 8). It is clearly seen from the graph that there is an increase in the inlet temperature from $300^{\circ} \mathrm{C}$ to $301.53^{\circ} \mathrm{C}$.

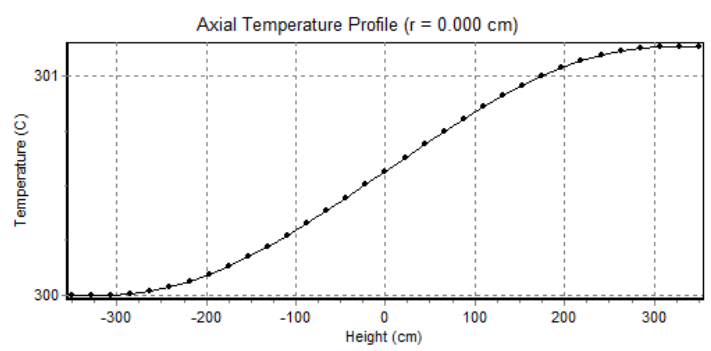

Figure 7. Axial coolant temperature distribution

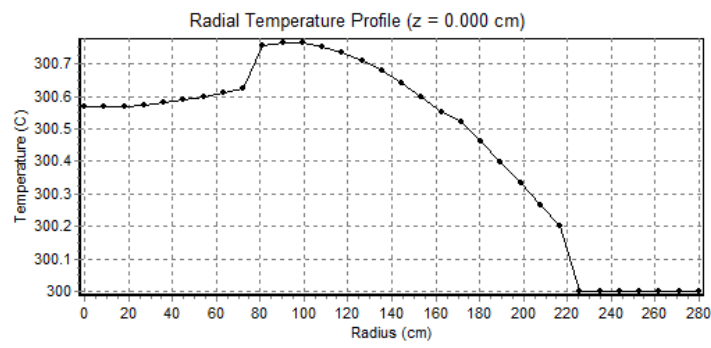

Figure 8. Radial coolant temperature distribution (Prenpac)

However, if it compare to thermalhydraulic calculation using MS Excel, as can be seen at figure 9 , it is obtained that the fuel surface temperature is $784.5^{\circ} \mathrm{C}$. In this regards, more than $470^{\circ} \mathrm{C}$ heat is transferred to the water as a coolant. 


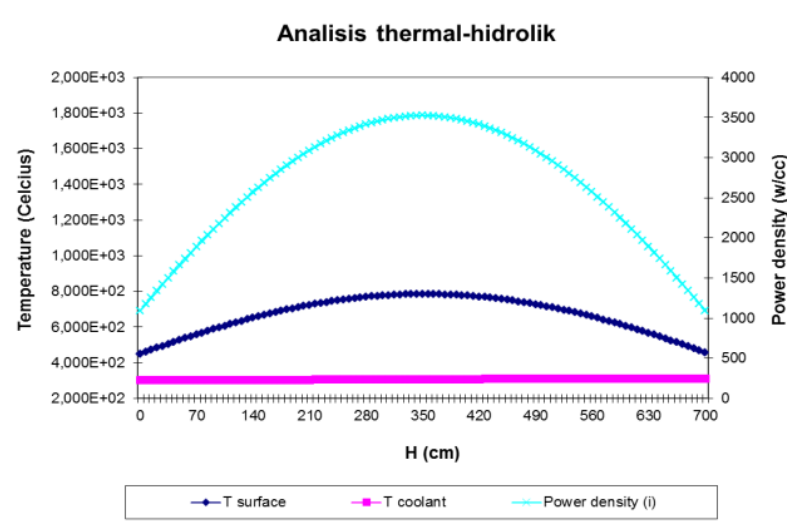

Figure 9. Profile of axial thermalhydraulic

(MS Excel)

In order to keep the reactor always be in critical condition $(\rho=0)$, it is necessary to control the reactivity at any time. By putting the external reactivity at 0:04 pcm, an increase in reactivity will be obtained for approximately 0.213 seconds, showed at Figure 10.

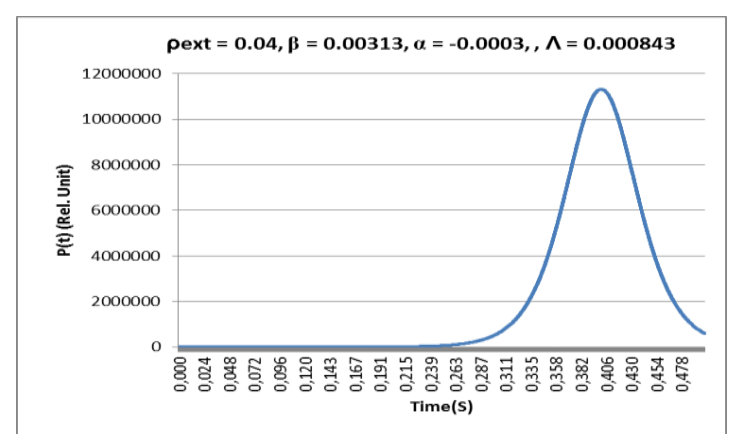

Figure 10. Changes in relative reactivity with time (at $\left.\rho_{\text {ext }}=0.04\right)$

These changes induce reactivity feedback of $-0.04 \mathrm{pcm}$ in 0.402 seconds. At the same time there is an increase of relative reactivity and then decrease back to zero. The feedback reactivity curve can be seen in Figure 11.

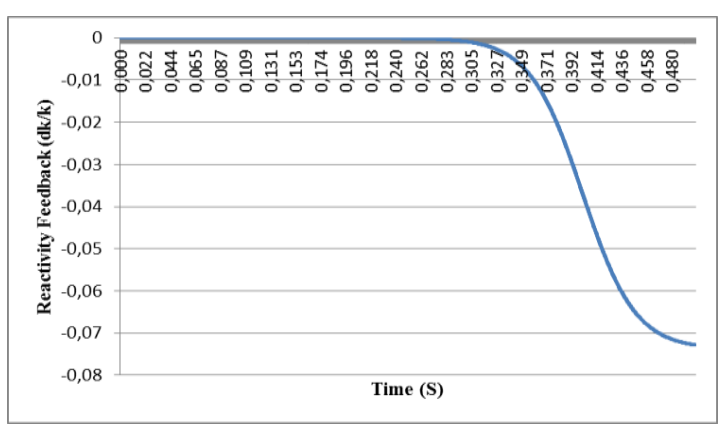

Figure 11. Changes in feedback reactivity $\left(\rho_{\text {ext }}=0.04\right)$

In this research, external reactivity are varied (from 0.03, 0.035, 0.04, 0.05, 0.06 and 0.07 ) in order to analyze the pattern of change in relative reactivity (figure 12) and feedback reactivity (figure 13).

variasi $\rho$ ext (pcm) $, \beta=0.00313, \alpha=-0.0003, \Lambda=0.000843$

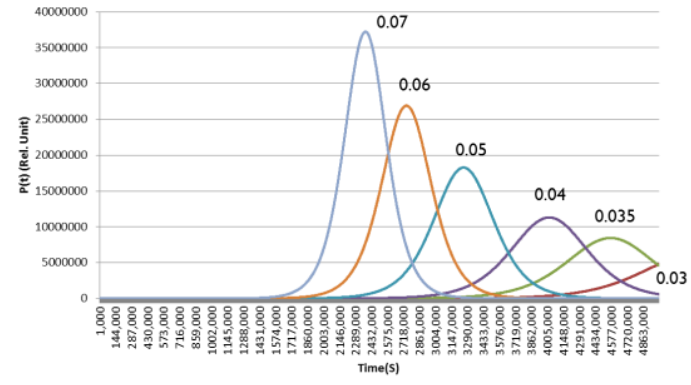

Figure 12. Relative reactivity changes

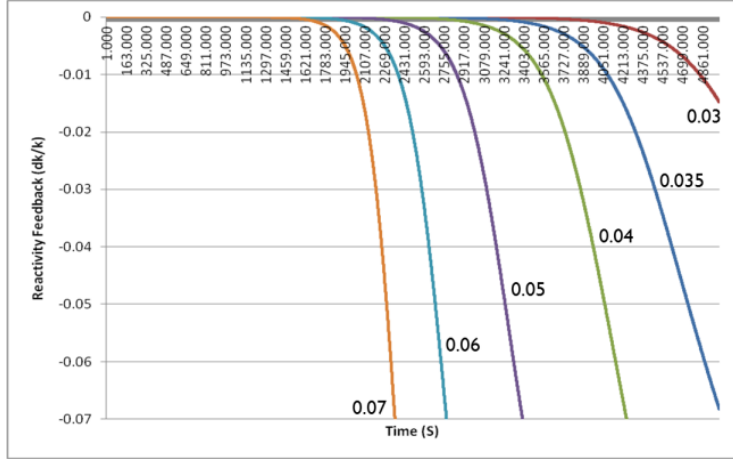

Figure 13. Feedback reactivity changes

\section{CONCLUSION}

Result of neutronic calculation and analysis showed that the value of initial $\mathrm{k}_{\mathrm{eff}}(0$ year) was 1.0107 and then decreased until the 7th year, then increased gradually until the $33^{\text {rd }}$ year. Level burn-up also increased, due to the additional fissile material as conversion results of Th232 and Pa231.

Linear power distribution axially follow a normal distribution pattern. The results of thermal-hydraulic analysis 
shows that the coolant temperature distribution in the axial direction which is quite flat.

\section{REFERENCES}

[1] Kazimi, M.S., Czerwinski, K.R., Driscoll, M.J., et all, 1996. On The Use Of Thorium In Light Water Reactors, Departement of Nuclear Engineering Massachussetts Institute of Technology, Cambridge. Massachusetts.

[2] Subkhi Moh. Nurul, Su'ud Zaki, and Waris Abdul., 2013. Neutronic Design of Small Long-Life PWR using Thorium Cycle. Advance Materials Research, Volum 772 page 524-529

[3] Subkhi, Moh. Nurul, Su'ud Zaki, and Waris Abdul. 2012. Design study of
Long-Life PWR using Thorium Cycle. AIP Conference Proceedings. 1448. 101 (2012)

[4] Pramuditya, S, et al., 2005, Integrated Computer Code Development Studies Preliminary Design For Nuclear Power PWR type, Department of Physics, Institut Teknologi Bandung, Bandung.

[5] Duderstadt, James J. and Louis J. Hamilton., 1976, Nuclear Reactor Analysis, John Wiley \& Sons, Inc, New York.

[6] Okumura, K., Kugo, T., Kaneko, K. and Tsuchihasi, K. 2002. SRAC. (Ver. 2002); The comprehensive neutronics calculation code system. Japan Atomic Energy Research Institute (JAERI), Japan. 